\title{
Integration of Open Educational Resources in Higher and General Education Institutions: from the Perspectives of Specialized and Concerned Bodies in E-Learning
}

\author{
Huda Y. Alyami ${ }^{1, *}$ \\ ${ }^{1}$ College of Education, Najran University, KSA \\ *Correspondence: College of Education, Najran University, KSA. E-mail: hyalyami@nu.edu.sa
}

Received: January 9, 2020

Accepted: January 31, 2020

Online Published: February 10, 2020

doi:10.5430/wje.v10n1p30

URL: https://doi.org/10.5430/wje.v10n1p30

\begin{abstract}
Open educational resourses have become a strategic source of a high degree of importance and this explains the reason for the acceleration of countries to join the use of them, but unfortunately, the results of a survey study conducted in the Kingdom of Saudi Arabia on eight experts in e-learning showed a gap that hinders integration in the use of open educational resources among educational institutions, especially at the general and higher education. Accordingly, the present study aimed to review the most prominent Open Educational Resources (OER) platforms in Saudi Arabia and identify the reality of cooperation and the best means of integration between higher and general education institutions from the perspective of specialists and concerned bodies. It adopted the analytical survey (descriptive) method. It covered a population of specialists and concerned bodies in e-learning from higher and general education institutions. The study applied a questionnaire to a sample of (144) participants from higher education institutions and (327) participants from general education institutions. Finally, it concluded results, made recommendations and suggested further studies.
\end{abstract}

Keywords: open educational resources (OER), higher education, general education, integration

\section{Introduction}

Knowledge has become a strategic asset in the 21 st century. It is a bridge to success. Traditional environments of teaching and learning are not adequate for keeping up with the knowledge-based economy that has become a global trend. Therefore, creative and motivating educational environments concerned with building and sharing knowledge should be established based on technology that is the main feature of change in educational institutions, because it allows platforms that transcend their spatial and temporal boundaries, especially OER.

According to UNESCO (2013), having a high-quality education is the key to peace and sustainable social and economic development. Many studies report that OER offer strategic opportunities to develop the quality of education. For example, Glennie, Harley, Butcher, and Wyk (2012) argue that OER are the future of education in developing countries, in particular.

Therefore, universities and educational institutions in Saudi Arabia have sought to join OER with a philosophy that education should accessible and open to all concerning the dissemination and sharing of knowledge freely online. They aspire to establish a knowledge society that guarantees quality education to all. As a result, hundreds of websites were established including massive educational resources, such as curricula, books, interactive lectures, and journals to be used for educational and research purposes free of charge (Altil, 2013).

To date, Saudi Arabia has sought to contribute effectively to free access. Therefore, a set of Saudi journals and digital repositories has been added to the international manuals of free access along with the free access projects of King Abdulaziz City for Science and Technology (KACST). The Saudi Digital Library supports and provides faculty members, researchers, and higher education students with access to OER. In addition, it offers all public sectors in Saudi Arabia access to OER in all fields (Almarwani, 2013).

\subsection{Problem of the Study}

Based on reviewing many OER and the opinions of many e-learning experts in Saudi Arabia in (8) extensive 
interviews, the Researcher noticed that despite the availability of OER in the educational institutions, these e-platforms and development efforts are on crossroads. Although there are many shared spaces, a gap hinders the integration of OER. Therefore, the study investigates the available means of integration of OER in higher and general education institutions, especially after merging the Ministry of Higher Education and the Ministry of Education to be the Ministry of Education in 2015 (Ministry of Education, 2020).and all so new communication horizons and fruitful work are established and Saudi government makes steady progress towards e-learning. It has established specialized centers, and taken specific initiatives, such as the National Center for E-Learning and Distance Learning (NCeDL) and the Saudi Digital Library (Adiab, Chowdhury, Kootsookos, and Alam, 2017).

As a result of what had been mentioned above the problem of the study can be stated in the following questions:

1. What are the prominent OER platforms in Saudi Arabia fromthe perspective of specialists?

2. What is the status of cooperation between higher and general education institutions in OER fromthe perspective of specialists?

3. What are the most notable means of integration between OER in higher and general education institutions from the perspective of specialists?

\subsection{The study Objectives}

1. Identify the main OER platforms in Saudi Arabia.

2. Prevail the reality of cooperation between higher and general education institutions in OER.

3. Define the most notable means of integration between OER in higher and general education institutions from the perspective of specialists.

\subsection{Importance of the Study}

1. It addresses an important issue concerning OER, i.e. the integration between higher and general education institutions.

2. It maximizes the benefit of OER in educational institutions as a step towards the development and enrichment of e-learning in higher and general education institutions.

\section{Literature Review}

Educational institutions endeavor to achieve a more flexible education. Technology that represents the main feature of change to education should be utilized. As a result, platforms beyond the boundaries of classrooms, especially OER, have emerged. They contain of materials for teaching, learning, or research purposes accessible to educators, students, and others globally free of charge. These materials are often published online under the creative commons license.

The term OER was introduced in the forum of the UNESCO in 2002, on the impact of OER on higher education in developing countries, which defined OER as "the open provision of educational resources, enabled by information and communication technologies, for consultation, use and adaptation by a community of users for non-commercial purpose" (UNESCO, 2002, p.24).

In 2004, UNESCO broadened the concept to include three important aspects in the educational process, namely the educational content, including schoolbooks, curricula, and lesson plans; tools, e.g. the programs that help produce and use the educational content and open technology that helps flexible collaborative learning and open participation of the teaching practices that help educators benefit from the best ideas and resources of the peers; the executive resources to ensure the quality of education, educational practices, and licensing of educational resources (Altil, 2013; Mosharraf and Taghiyareh, 2016).

Since their introduction, OER have spread significantly all over the world in the different educational, training, and research institutions (DeVries, 2013; Kwak, 2017) because of their evolving advantages to improve the effectiveness of teaching and learning and developing the institutions and employees. Experts and specialists believe that they have affected teaching and learning positively. Thus, many educational institutions have adopted them totally or partially.

Many studies on OER reported their significant impact on education, improving its quality and efficiency in providing the educational resources to students, and economy that makes OER the preferable option for many educational institutions (Delgado, Delgado, Hilton, 2019; Vojtech and Grissett, 2017; Mosharraf and Taghiyareh, 
2016). Globally, Baas, Admiraal, and van den Berg (2019) argued that OER have full capacity to cause positive change to higher education. However, adoption is still limited. They conducted a descriptive study and applied a questionnaire to (143) experienced teachers in OER. Results revealed the importance of supporting OER and the establishment of national and institutional teacher communities. The results agree with (Kwak, 2017) as the results revealed that $92 \%$ of the students believe that teachers have an essential role in encouraging the use of OER, The study ascertains the big value of using the OER in formal educational curricula, but shortage of knowledge about adaptation of the OER interferes with the full use of it and reduces its potentials in practical application.

Hilton (2016) reviewed the results of (16) studies on the effectiveness and perceptions of OER in higher education. These results revealed that OER users and commercial curriculum materials' users generally achieve the same learning outcomes. Furthermore, both students and educators have general perspectives on OER.

Hilton (2019) reviewed the results of (16) studies on the efficacy and (20) studies on the perceptions covering 121 and 168 students and faculty members. The study examined the efficacy of university education and the perceptions of university students and faculty members who used OER. Many studies concluded that students achieve the same or better learning outcomes, as well as substantial savings when using OER. In addition, most of the faculty members and students who used OER had positive attitudes. Luo, Hostetler, Freeman, and Stefaniak (2019) analyzed (51) OER studies across the five continents. They reported no significant difference in learning outcomes when educators incorporate OER. Moreover, educators and designers hope that OER may replace traditional content effectively.

Referring to the previous studies which included the OER in higher education we find a consensus among these descriptive and analytical studies about the effectiveness of OER at international level, the studies focused on the positive perspectives of both the teachers and the students on using OER in the current time and also in the future which also agrees with the current study in framing the effectiveness of OER in higher education institutions, it also considers the the higher education institutions as an essential component in the system of OER and an active partner beside the other educational institutions in achieving the required integration among these resourses wich serve an extended sector of beneficieries in all educational institutions at different levels.

Many studies examined the impact of using OER in general education institutions. For example, Hilton, Larsen, Wiley, and Fischer (2019) reported that OER could be an alternative to commercial curriculum materials. They compared the end-of-year mathematics test results of $(12,110)$ elementary school students within $(95)$ schools from five school districts in Washington, the USA. While $(6,796)$ students used OER, $(5,314)$ utilized commercial curriculum materials. Over three years, there were no statistically significant differences in the exam scores of students who used OER versus commercial curriculum materials. Roberts (2019) analyzed studies on the development of open educational practices in K-12 learning contexts. The study concluded that OER are a personal educational experience beyond formal learning environments.

The study of (Wong, Xie, Zou, Wang, Tang, Kong, \& Kwan, 2019) focused on studying the organized self- learning using the OER instead of traditional teaching for students of elementary schools, this was done by conducting three surveys that included three samples represented by 150,168 and 149 students respectively. The results of the study concluded that OER can not only help students learn in formal classrooms, but can also help students' self-organized learning. The study (Sulisworo, Sulistyo, \& Akhsan, 2017) also aimed to consider the impact of the application of OER on stimulating student learning in one of the high schools in Indonesia, and the study to achieve that goal followed the quasi-experimental approach with two experimental groups of (34) students, and the control that included (27) students, the results concluded that the student satisfaction with learning using OER tends to be similar to traditional face-to-face learning, and the results also indicate the positive impact of OER on stimulating student learning.

By reviewing the previous quantitative and qualitative studies that addressed OER at the level of general education, we find that there is a complete agreement between these studies on the effectiveness of OER at all educational levels, where the effectiveness of OER is similar to the effectiveness of high-cost commercial resources. When comparing all studies that dealt with OER in higher education and general education, it is noted that the results of all of these studies are in favor of using those resources that have proven their efficiency in educational institutions of all levels from kindergarten to university.

Despite the efficiency and positive impact of using OER on higher and general education institutions, OER often help process and provide the needs of higher education rather than general education institutions, especially the primary and high stages (Tosato, Arranz, and Avi, 2014). In addition, many statements show the difficulty of establishing a community of practices on OER. Without a collaborative environment to involve a large number of users, it may be difficult to stimulate sharing and finding new resources and improve the practices of educators. 
In short, OER are an important aspect of education in the contemporary knowledge society and a tool of sustainable development that creates opportunities for continuous cognitive, professional, and economic learning and transcends the social, economic, and geographical boundaries. To achieve the potential and enhance the educational impact of OER, it is important to develop and improve them in all aspects, including lectures, images, audio-video files, course materials, training courses, full curricula, textbooks, as well as other programs, tools, and techniques to build and access knowledge. OER provide renewable spaces of knowledge production and sharing, as well as promoting an adequate educational environment for the needs of individuals and institutions.

Therefore, higher and general education institutions should be integrated into OER as a vital area highlighted by many studies and as a way to establish a participatory work environment to produce and develop high-quality OER. The open educational practices should be promoted to improve the quality of general and higher education, and outputs to enable the learners and educators to employ these resources in contexts that promote the skills of the $21^{\text {st }}$ century and contribute to professional development.

Educators and students within higher and general education share the need for high-quality educational resources to assist in the pursuit of teaching and learning. "Although there are numerous differences between the two levels of education, there are commonalities in the perceptions of the purpose, practical uses, and challenges" (Blomgren, 2018, p.55). Promoting the existing educational communities is a key factor in the development of the educational model of open content. The development of open and sustainable practice is a vital issue in any educational model and should not be separated from the existing ones. Instead, effective networks should be promoted. The affiliated communities and institutions strongly need to share common interests and innovative approaches to open access to educational resources. Consequently, economic efficiency will be achieved, and the level of education and learning should be raised (Yuan, MacNeill, \& Kraan, 2008).

Aleanzi (2016) investigated the obstacles to achieve educational integration between general and higher education. The study reported many obstacles to such integration related to some aspects, i.e. communication, coordination, and exchange. A common strategy between both types of education is absent, which results a big gab and hinders the desired integration. Therefore, strategies and models should be developed to achieve integration.

The report of the seventeenth conference of the Saudi Society for Educational and Psychological Sciences (2017) entitled "educational integration between general and higher education" recommended the need to achieve integration at all levels between the two sectors and setting mechanisms of integration focusing on the educator, learner, method, and scientific research. Because of the inclusiveness of OER, UNESCO (2017) reported that they prepare and qualify students for success in active knowledge societies in the $21^{\text {st }}$ century. They provide students with new concepts independently in the different stages of education. The educational institutions should be integrated to create a common ground and unite efforts to build and develop OER in higher and general education to share capabilities and experience and improve the common quality outcomes. Therefore, the present study investigates the means of integration between the general and higher education institutions in OER in the Kingdom of Saudi Arabia.

As the movement of OER is witnessing remarkable growth in the Kingdom of Saudi Arabia, which has been keen on positive engagement in the field of free access to OER and has resulted in many projects, initiatives and contributions in that field, which was mentioned in details by (Almarwani, 2013) in his study allowing electronic access to all of these resources. The Kingdom of Saudi Arabia continues its efforts in the field of OER represented by the NCeDL, which worked to establish an institutional framework for OER that guarantees the sustainability of those resources. The NCeDL is the national program for OER, as the program contributes to enhancing educational content to support university education, and through this program several initiatives emerged, most notably the OER network Shams, which was launched on March the fifth, 2018 (NCeDL, 2019). The NCeDL won the Excellence Award in Open Education for the year 2018, represented in his initiative, the Saudi Resources Network "Shams" by the International Federation for Open Education (The official Saudi Press Agency, 2018). Based on the preceding, we find that there is a stable base for OER in the Kingdom and a fertile environment for developing practices and partnerships in the field of OER, which is what the current study means to address.

\section{Method}

\subsection{Curriculum of the Study}

The study follows the descriptive analytical method as it fits with the nature of this study since it depends on study of the phenomeno as it exist in reality and is interested as an accurate description and expresses it qualitatively or quantitatively. 


\subsection{Population and Sample of the Study}

The study covered a population of educational leaders in general and higher education,university faculty members, teachers in general education and concerned bodies in e-learning who are experienced in OER from higher and general education institutions in the first semester of 2018/2019. It included a randomly selected sample from the population, representing the various areas of Saudi Arabia.

1. Higher education institutions: (144) participants from all public universities in Saudi Arabia according to the academic degree.

Table 1. The Participants Classification

\begin{tabular}{lllll}
\hline Academic degree & Full professor & Associate professor & Assistant Professor & Lecturer \\
\hline Number & 13 & 19 & 71 & 41 \\
\hline
\end{tabular}

Table 1 shows the distribution of the study sample from specialists and those who are interested in open educational resources in higher education institutions according to thier degree.

2. General education institutions: (327) participants in the educational departments and schools of various stages.

\subsection{Study Tool}

The questionnaire was used to achieve the purposes of the study, and it was built based on the following steps:

a. In consideration of the objectives and its variables, the aim of the tool (questionnaire) was determined. It is searching for ways of integrati9on in (OER) between higher and general education, and to find out thereality of the use of these educational resources by open institutions in addition to identify the status of cooperation between those institutions. Also, the open/ closed questionnaire style was chosen because it is more efficient in achieving the objectives of the study. (4) items of the questionere are open ended question, (13) of the items are closed questions.

b. After that, a comprehensive survey was conducted for all the local, regional and international literature and studies that related to the subject of the study in order to form an accurate perception of these opportunities and challenges. The opinion of specialists from teachers and educators- which has collected through meetings and interviews- had been all in consideration. In consequence, information that represent the integration between higher and general education in the field of open educational resources has been collected.

c. Afterthat, the questionnaire has been wrote and drafted based on what was stated in theoretical literature, and based on what was issued by the opinions of specialized professors in this regard, and by referring to the researcher's experience in this field, and in light of the general controls for writing the questionnaire, the questionnaire were drafted and presented to the arbitrators, and then take into account the arbitrators' notes and work on them.

\subsection{Validity of the Questionnaire}

The apparent honesty of the questionnaire was confirmed by presenting it to a number of arbitrators with a specialization in the field of educational technology, open education, and based on the observations and proposals of the arbitrators, adjustments were made to the questionnaire.

\subsection{Reliability of the Questionnaire}

To ensure the consistency of the questionnaire, the internal consistency coefficients were calculated using the Alpha Cronbakh equation, where the coefficient of stability of the study instrument reached $(0,89)$. This percentage is considered high and confirms that the tool is characterized by a high coefficient of stability, which means that it has a high degree of internal consistency within its context and this is considered as an indication of the tool's relevance to a large extent in its application.

\subsection{Procedures for Applying the Study Tool (Questionnaire)}

The questionnaire was distributed to the sample in hard and electronic formats via workshops of the open educational resources' initiative of the National Center for e-learning and distance education, which represents the largest practice community for specialists and those who are interested in the field of open educational resources. Later, the questionnaires were calculated, data were extracted, processed, and analyzed statistically, and results were concluded. 


\section{Results}

\subsection{Answer to the $1^{\text {st }}$ Question}

Based on the statistical analysis of data collected by the study tool (the questioner), a list of the most prominent OER in Saudi Arabia was obtained, as follows:

a. SHMS - Saudi OER Network by NCeDL in 2018

b. Digital repositories in higher education institutions, such as The National Repository of the Educational Modules (Maknaz), Repository of King Abdullah University of Science and Technology, Digital Repository of King Fahd University of Petroleum and Minerals categorized with the standard digital repositories in the Arab World, Digital Repository of King Saud University, Digital Repository of Umm Al-Qura University, and repositories of e-learning systems in some Saudi universities.

c. Saudi Digital Library

d. Saudi Journals: Annals of Saudi Medicine, Journal of Family and Community Medicine, Saudi Dental Journal, and Saudi Journal of Anesthesia.

e. Massive open online courses (MOOC), e.g. Rewaq.

\subsection{Answer to the $2^{\text {nd }}$ Question}

The results of the statistical analysis of data collected by the study tool (the questioner) revealed the status of cooperation between higher and general education institutions in OER in Saudi Arabia as follows

(A) The status of adopting and sharing OER in higher and general education institutions:

In higher education institutions, (68.4\%) reported the lack of OER in their institutions, (30.2\%) indicated a lack of knowledge about the existence of OER despite their interest, and (1.4\%) stressed the existence of OER, such as the Saudi Digital Library and JUSUR. In general education institutions, $(83.5 \%)$ reported the lack of OER in their institutions, and (16.5\%) indicated a lack of knowledge about the existence of OER.

(B) The status of the existing cooperation between the educational institutions in OER:

In higher education institutions, (51.8\%) reported the lack of cooperation between their institutions and other institutions in OER, (40.1\%) indicated the lack of knowledge about cooperation, and (8.1\%) reported cooperation with international academic bodies. In general education institutions, $(89.8 \%)$ reported the lack of cooperation between their institutions and other institutions in OER, and (9.2\%) indicated the lack of knowledge about cooperation.

(C) Future trends/ projects of cooperation between higher and general education institutions in OER:

The participants agreed on the lack of current projects and the lack of knowledge of future ones. However, they highlighted the potential cooperation, especially after merging the Ministry of Higher Education and the Ministry of Education.

\subsection{Answer to the $3^{\text {rd }}$ Question}

The prominent means of integration between higher and general education institutions in OER from the perspective of specialists and concerned bodies were defined by analyzing the responses of the participants.

(A) Results of the questionnaire applied to the specialists and concerned bodies in higher education institutions: 
Table 2. Results of a Questionnaire of Specialists and Those Who are Interested in Open Educational Resources in Higher Education Institutions

\begin{tabular}{|c|c|c|c|c|c|c|c|c|}
\hline \multirow{3}{*}{ No. } & \multirow{3}{*}{$\begin{array}{l}\text { Integration means of OER between higher and } \\
\text { general education institutions }\end{array}$} & $\begin{array}{l}\text { Strongly } \\
\text { agree }\end{array}$ & Agree & $\begin{array}{c}\text { Somew } \\
\text { hat }\end{array}$ & Disagree & $\begin{array}{l}\text { Strongly } \\
\text { disagree }\end{array}$ & \multirow{3}{*}{$\begin{array}{l}\text { Weighted } \\
\text { mean }\end{array}$} & \multirow{3}{*}{$\begin{array}{l}\text { Standard } \\
\text { deviation }\end{array}$} \\
\hline & & Number & Number & Number & Number & Number & & \\
\hline & & $\%$ & $\%$ & $\%$ & $\%$ & $\%$ & & \\
\hline 1 & $\begin{array}{l}\text { OER addressing of the issues of the } 21^{\text {st }} \text { century } \\
\text { (i.e. global awareness; financial, economic, } \\
\text { administrative, and entrepreneurial culture; civil/ } \\
\text { national culture; health culture; environmental } \\
\text { culture) }\end{array}$ & $52.7 \%$ & $30.5 \%$ & $16.6 \%$ & - & - & 4.36 & 0.753 \\
\hline 2 & $\begin{array}{l}\text { Integrating the skills of the } 21^{\text {st }} \text { century in OER } \\
\text { (creativity, innovation, cooperation, teamwork, } \\
\text { leadership, cross-cultural understanding, } \\
\text { communication and information culture, } \\
\text { technology and cyberculture, and self-reliance in } \\
\text { learning and work) }\end{array}$ & $50 \%$ & $36.11 \%$ & $13.8 \%$ & 0 & $\mathbf{0}$ & 4.36 & 0.715 \\
\hline 3 & $\begin{array}{l}\text { Providing training materials to qualify and train } \\
\text { academicians and educators in the education of } \\
\text { the } 21^{\text {st }} \text { century }\end{array}$ & $66.6 \%$ & $25 \%$ & $8.33 \%$ & 0 & 0 & 4.58 & 0.642 \\
\hline 4 & $\begin{array}{l}\text { The development of networks between OER in } \\
\text { general education and research centers in higher } \\
\text { education institutions to exchange ideas and } \\
\text { experiences }\end{array}$ & $66.6 \%$ & $19.44 \%$ & $11.11 \%$ & $2.77 \%$ & 0 & 4.5 & 0.802 \\
\hline 5 & $\begin{array}{l}\text { Conducting joint projects between higher and } \\
\text { general education via OER for community } \\
\text { partnership }\end{array}$ & $58.33 \%$ & $16.66 \%$ & $19.44 \%$ & $5.55 \%$ & 0 & 4.27 & 0.963 \\
\hline 6 & $\begin{array}{l}\text { Developing the curricula and components in OER } \\
\text { by academicians in higher education and } \\
\text { concerned bodies in general education institutions }\end{array}$ & $72.22 \%$ & $13.8 \%$ & $8.33 \%$ & 0 & $5.55 \%$ & 4.47 & 1.044 \\
\hline 7 & $\begin{array}{l}\text { Qualifying students in general education } \\
\text { institutions for the appropriate specializations }\end{array}$ & $\begin{array}{c}92 \\
63.88 \%\end{array}$ & $\begin{array}{c}28 \\
19.44 \%\end{array}$ & $\begin{array}{c}16 \\
11.11 \%\end{array}$ & 0 & $\begin{array}{c}8 \\
5.55 \%\end{array}$ & 4.36 & 1.061 \\
\hline 8 & $\begin{array}{l}\text { Developing comprehensive manuals on university } \\
\text { specializations based on labor market needs }\end{array}$ & $\begin{array}{c}96 \\
66.6 \%\end{array}$ & $\begin{array}{c}20 \\
13.88 \%\end{array}$ & $\begin{array}{c}16 \\
11.11 \%\end{array}$ & $\begin{array}{c}4 \\
2.77 \%\end{array}$ & $\begin{array}{c}8 \\
5.55 \%\end{array}$ & 4.33 & 1.134 \\
\hline 9 & $\begin{array}{l}\text { Building joint test banks between higher and } \\
\text { general education on student attitudes and } \\
\text { capabilities }\end{array}$ & $66.6 \%$ & $11.11 \%$ & $19.44 \%$ & 0 & $2.77 \%$ & 4.38 & 0.983 \\
\hline 10 & $\begin{array}{l}\text { Provision of resources that help consolidate the } \\
\text { efforts of higher and general education institutions } \\
\text { to support substantial development plans }\end{array}$ & $61.11 \%$ & $25 \%$ & $11.11 \%$ & $2.77 \%$ & 0 & 4.44 & 0.800 \\
\hline 11 & $\begin{array}{l}\text { Provision of resources to consolidate the national, } \\
\text { Arab, and Islamic identity via OER }\end{array}$ & $\begin{array}{c}92 \\
63.88 \%\end{array}$ & $\begin{array}{c}20 \\
13.88 \%\end{array}$ & $\begin{array}{c}28 \\
19.44 \%\end{array}$ & $\begin{array}{c}4 \\
2.77 \%\end{array}$ & 0 & 4.38 & 0.893 \\
\hline 12 & $\begin{array}{l}\text { Provision of resources to support solidarity with } \\
\text { the local, Arab, and Islamic issues }\end{array}$ & $\begin{array}{c}88 \\
61.11 \%\end{array}$ & $\begin{array}{c}32 \\
22.22 \%\end{array}$ & $\begin{array}{c}20 \\
13.88 \%\end{array}$ & 0 & $\begin{array}{c}4 \\
2.77 \%\end{array}$ & 4.38 & 0.924 \\
\hline 13 & $\begin{array}{l}\text { Building and developing Arabic lexicons in all } \\
\text { fields via OER }\end{array}$ & $\begin{array}{c}96 \\
66.66 \%\end{array}$ & $\begin{array}{c}28 \\
19.44 \%\end{array}$ & $\begin{array}{c}8 \\
5.55 \%\end{array}$ & $\begin{array}{c}12 \\
8.33 \%\end{array}$ & 0 & 4.44 & 0.929 \\
\hline
\end{tabular}


Table 2 reviews the opinions of specialists and those who are interested in the field of open educational resources in higher education institutions about the most important ways of integration between higher and general education institutions in the field of open educational resources

The table shows that all responses were rated (strongly agree), suggesting the need to bridge the gap between higher and general education in OER. "Providing training materials to qualify and train academicians and educators in the education of the $21^{\text {st }}$ century" was ranked first, while "conducting joint projects between higher and general education via OER for community partnership" was ranked last.

(A) Results of the questionnaire applied to the specialists and concerned bodies in general education institutions:

Table 3. Results of a Questionnaire of Specialists and Those Who are Interested in Open Educational Resources in Higher Education Institutions

\begin{tabular}{|c|c|c|c|c|c|c|c|c|}
\hline \multirow[t]{2}{*}{ No. } & \multirow[t]{2}{*}{$\begin{array}{l}\text { Integration means of OER between higher and } \\
\text { general education institutions }\end{array}$} & $\begin{array}{l}\text { Strongly } \\
\text { agree }\end{array}$ & Agree & Somewhat & Disagree & $\begin{array}{l}\text { Strongly } \\
\text { disagree }\end{array}$ & \multirow[t]{2}{*}{ M } & \multirow[t]{2}{*}{ S.D } \\
\hline & & $\begin{array}{c}\text { Number } \\
\%\end{array}$ & $\begin{array}{c}\text { Number } \\
\%\end{array}$ & $\begin{array}{c}\text { Number } \\
\% \\
\end{array}$ & $\begin{array}{c}\text { Number } \\
\% \\
\end{array}$ & $\begin{array}{c}\text { Number } \\
\% \\
\end{array}$ & & \\
\hline \multirow[t]{2}{*}{1} & $\begin{array}{l}\text { OER addressing of the issues of the } 21 \text { st century } \\
\text { (i.e. global awareness; financial, economic, } \\
\text { administrative, and entrepreneurial culture; civil/ } \\
\text { national culture; health culture; environmental } \\
\text { culture). }\end{array}$ & 164 & 120 & 34 & 0 & 9 & 4.31 & 0.869 \\
\hline & & $50.15 \%$ & $36.69 \%$ & $10.39 \%$ & 0 & $2.75 \%$ & & \\
\hline \multirow[t]{2}{*}{2} & $\begin{array}{l}\text { Integrating the skills of the } 21^{\text {st }} \text { century in OER } \\
\text { (creativity, innovation, cooperation, teamwork, } \\
\text { leadership, cross-cultural understanding, } \\
\text { communication and information culture, } \\
\text { technology and cyberculture, and self-reliance in } \\
\text { learning and work). }\end{array}$ & 159 & 138 & 21 & 0 & 9 & 4.33 & 0.827 \\
\hline & & $48.62 \%$ & $42.20 \%$ & $6.42 \%$ & 0 & $2.75 \%$ & & \\
\hline \multirow[t]{2}{*}{3} & $\begin{array}{l}\text { Providing training materials to qualify and train } \\
\text { academicians and educators in the education of the } \\
21^{\text {st }} \text { century. }\end{array}$ & 225 & 84 & 6 & 6 & 6 & 4.57 & 0.782 \\
\hline & & $68.80 \%$ & $25.68 \%$ & $1.83 \%$ & $1.83 \%$ & $1.83 \%$ & & \\
\hline \multirow[t]{2}{*}{4} & $\begin{array}{l}\text { The development of networks between OER in } \\
\text { general education and research centers in higher } \\
\text { education institutions to exchange ideas and } \\
\text { experiences. }\end{array}$ & 207 & 90 & 18 & 6 & 6 & 4.48 & 0.832 \\
\hline & & $63.30 \%$ & $27.52 \%$ & $5.50 \%$ & $1.83 \%$ & $1.83 \%$ & & \\
\hline \multirow[t]{2}{*}{5} & $\begin{array}{l}\text { Conducting projects between higher and general } \\
\text { education via OER for community partnership }\end{array}$ & 201 & 90 & 24 & 6 & 6 & 4.44 & 0.852 \\
\hline & & $61.46 \%$ & $27.52 \%$ & $7.33 \%$ & $1.83 \%$ & $1.83 \%$ & & \\
\hline \multirow[t]{2}{*}{6} & $\begin{array}{l}\text { Developing the curricula and components in OER } \\
\text { by academicians in higher education and } \\
\text { concerned bodies in general education institutions. }\end{array}$ & 201 & 93 & 21 & 6 & 6 & 4.45 & 0.842 \\
\hline & & $61.46 \%$ & $28.44 \%$ & $6.42 \%$ & $1.83 \%$ & $1.83 \%$ & & \\
\hline \multirow[t]{2}{*}{7} & $\begin{array}{l}\text { Qualifying students in general education } \\
\text { institutions for the appropriate specializations. }\end{array}$ & 231 & 69 & 15 & 6 & 6 & 4.56 & 0.818 \\
\hline & & $70.64 \%$ & $21.10 \%$ & $4.58 \%$ & $1.83 \%$ & $1.83 \%$ & & \\
\hline \multirow[t]{2}{*}{8} & $\begin{array}{l}\text { Developing comprehensive manuals on university } \\
\text { specializations based on labor market needs. }\end{array}$ & 207 & 93 & 18 & 3 & 6 & 4.50 & 0.798 \\
\hline & & $63.30 \%$ & $28.44 \%$ & $5.50 \%$ & $0.91 \%$ & $1.83 \%$ & & \\
\hline \multirow[t]{2}{*}{9} & $\begin{array}{l}\text { Building joint test banks between higher and } \\
\text { general education on student attitudes and } \\
\text { capabilities. }\end{array}$ & 189 & 93 & 30 & 6 & 9 & 4.36 & 0.926 \\
\hline & & $57.79 \%$ & $28.44 \%$ & $9.17 \%$ & $1.83 \%$ & $2.75 \%$ & & \\
\hline
\end{tabular}




3

6

4.41

0.849

to support substantial development plans.

Provision of resources to consolidate the national, Arab, and Islamic identity via OER.

Provision of resources to support solidarity with the local, Arab, and Islamic issues.

Building and developing Arabic lexicons in all fields via OER.

\begin{tabular}{ccccccc}
$58.71 \%$ & $28.44 \%$ & $10.09 \%$ & $0.91 \%$ & $1.83 \%$ & & \\
216 & 78 & 27 & 0 & 6 & 4.52 & 0.797 \\
& & & & & & \\
$66.05 \%$ & $23.85 \%$ & $8.25 \%$ & 0 & $1.83 \%$ & & \\
189 & 84 & 45 & 3 & 6 & 4.36 & 0.886 \\
$57.79 \%$ & $25.68 \%$ & $13.76 \%$ & $0.91 \%$ & $1.83 \%$ & & \\
201 & 93 & 27 & 0 & 6 & 4.47 & 0.797 \\
$61.46 \%$ & $28.44 \%$ & $8.25 \%$ & 0 & $1.83 \%$ & & \\
\hline
\end{tabular}

Table 3 reviews the opinions of specialists and those interested in the field of open educational resources in public education institutions about the most important ways of integration between higher and general education institutions in the field of open educational resources.

The table illustrates that the integration of OER between higher and general education institutions is a major concern for the specialists and concerned bodies in general education. "Providing training materials to qualify and train academicians and educators in the education of the $21^{\text {st }}$ century" was ranked first, while "OER addressing of the issues of the 21 st century" was ranked last.

\section{Discussion}

In light of the results reviewed to answer the first question, which was stipulated by the most prominent open educational resource platforms in the Kingdom of Saudi Arabia, we still can notice that despite the encouragement that resulted in many initiatives and projects in this field, it is difficult to access the available OER in Saudi Arabia because of the lack of specialized manuals or supporting bodies, as well as the shortage of available data on the official websites. Based on her experience and the opinions of specialists, the researcher found out a severe shortage in the available data on most of the OER and access mechanisms.

The results of the answer to the second question are extrapolated the status of cooperation between higher and general education institutions in OER, through reviewing the opinions of specialists and those who are interested in the open educational resources in higher and general education, we find that the proportions are close to the status of educational institutions adopting open educational resources, although higher education institutions are better considering $1.4 \%$ of the study sample in higher education institutions. The result of this study is consistent with a study of (Tosato, et al.,2014), which concluded that open educational resources are more concerned with covering the needs of higher education without general education institutions, especially primary and secondary levels.

By looking at the status of partnerships between educational institutions in the field of open educational resources, we find that the preference here was also in favor of higher education institutions, as $8.1 \%$ of the study sample, which included specialists and those who are interested in open educational resources in higher education, indicated that there are partnerships between their institutions and academic destinations outside the Kingdom of Saudi Arabia, while the sample of the study that included specialists and those who are interested in open educational resources in general education did not indicate the existence of partnerships linking their institutions with other patiners. Also, the results did not indicate the existence of any existing partnerships between higher and general education institutions in the field of open educational resources, which is consistent with a study of (Al-Enezi, 2016) that indicated the absence of integration between general and higher education institutions according to the dimensions of communication, coordination and exchange that works to increase productivity.These results confirm the current study indicates that there is a common workspace which prepared for serious and integrated work between general and higher education institutions in order to improve the outputs of those institutions and achieve their efficiency. This study is looking for the best way to achieve the desired integration between higher and general education institutions, which is consistent with the results of the study of (Baas, et al., 2019) that emphasized the need to support open educational resources and the creation of national and institutional teacher communities.

In extrapolating the results of the opinions of specialists and those who are interested in open educational resources in general and higher education institutions -that are detailed in Table (2) and (3), it is noted that these results are 
partly consistent with the results of Al-Anzi study (2016), which indicated the lack of integration between higher and general education institutions, so the study called for achieving integration between general and higher education institutions through several strategies. Also, the current study considers that the open educational resources represent the most prominent one, and these results are also consistent with the study of (Blomgren, 2018), which indicates that despite the many differences between educational levels in higher and general education institutions, there is a partnership between those institutions in educational, practical and training uses as well as challenges of those educational institutions and their employees in general. Moreover, the current study is also consistent with a study of (Yuan, et al., 2008), which confirms that educational institutions and their employees are in urgent need to share common interests and innovations for providing open access to high-quality educational resources, and thus achieve economic efficiency and raise the level of education and learning in all higher and general education institutions. This remarkable agreement between the previous studies and the current study may be attributed to the opportunities and capabilities that open educational resources provide to educational institutions of all levels, as open educational resources have proven its efficiency in both higher and general education institutions alike. Also, the partnership between those institutions in the field of open educational resources may take them to high levels where the outcome are needed to be improved.

\section{Recommendations}

In the light of the goals and \& results, the study recommends the following:

1. Motivating and training educators and students, supporting, and disseminating the culture of free access and OER in the educational institutions in Saudi Arabia.

2. Exploration of cooperation among the universities and educational institutions and making strategic plans to adjust OER for the shared needs of the higher and general education in Saudi Arabia.

3. Localization of OER in the higher and general education institutions and motivating them to develop a collaborative framework in the field.

4. Initiating local dialogues between higher and general education institutions to identify their current and future needs of OER.

5. Reviewing and benefiting from the international efforts and experiences in OER, as well as keeping up with the requirements of the knowledge age based on the requirements of the local environment.

6. Conducting evaluative studies on OER in Saudi Arabia, in particular, and the Arab states, in general.

7. Supporting scientific research in OER.

8. Establishing a system of incentives to motivate educators to use OER.

9. Discussing the issues of intellectual property rights and setting mechanisms to preserve the rights of the participants.

10. Creating and publishing manuals of the channels and platforms of OER via the website of the Ministry of Education for the members of the educational community.

11. Working to achieve integration between higher and general education institutions in the field of open educational resources, in view of the ways of integration indicated by the current study.

\section{Suggestions}

Based on the results, the following topics are suggested for future study:

1. Establishing OER concerning the $21^{\text {st }}$ century skills between higher and general education.

2. Launching a joint initiative of OER between higher and general education institutions concerning the $21^{\text {st }}$ century skills.

\section{Conclusion}

This study came to emphasize the importance of OER in educational institutions of all kinds, and highlights the current and future status of educational resources in those institutions, where the problem of the study highlights a gap between general and higher education institutions in relation to OER. The current study examined the most prominent OER platforms in educational institutions in the Kingdom of Saudi Arabia, as well as ways to integrate 
OER between higher and general education institutions from the point of view of specialists in educational institutions. The study concluded that the way is available for cooperation between the general and higher education institutions in the field of OER. The study also provided a range of ways of integration available between these institutions and these are important results of the study because they provide insights that will open the development of educational resources in the Kingdom.

\section{Acknowledgements}

The researcher is deeply grateful to Dr. Yassir Almalki for his support to complete this research.

\section{References}

Aldiab, A., Chowdhury, H., Kootsookos, A., \& Alam, F. (2017). Prospect of eLearning in higher education sectors of Saudi Arabia: A review. Energy Procedia, 110, 574-580. https://doi.org/10.1016/j.egypro.2017.03.187

Aleanzi, Fayez. (2016). Obstacles to achieving educational integration between public education and higher education from the viewpoint of educational leaders in the northern border region. Journal of Education and Psychology message, 53, 287-310.

Almarwani, M. (2013). OER in Saudi Arabia. Retrieved 23 September, 2019 from http://poerup.referata.com/w/images/OER_in_Saudi_Arabia.pdf

Altil, Kalifah. (2013). Open Educational Resources: Teaching and Learning Challenges in Arab Countries. The second international conference of Omani Society for Education Technologies. Oman.

Baas, M., Admiraal, W., \& van den Berg, E. (2019). Teachers' Adoption of Open Educational Resources in Higher Education. Journal of Interactive Media in Education, 2019(1), 1-11. https://doi.org/10.5334/jime.510

Blomgren, C. (2018). OER awareness and use: The affinity between higher education and K-12. International Review of Research in Open and Distributed Learning, 19(2), 56-70. https://doi.org/10.19173/irrodl.v19i2.3431

Delgado, H., Delgado, M., \& Hilton III, J. (2019). On the Efficacy of Open Educational Resources: Parametric and Nonparametric Analyses of a University Calculus Class. International Review of Research in Open and Distributed Learning, 20(1), 184-203. https://doi.org/10.19173/irrodl.v20i1.3892

DeVries, I. (2013). Evaluating open educational resources: Lessons learned. Procedia-Social and Behavioral Sciences, 83, 56-60. https://doi.org/10.1016/j.sbspro.2013.06.012

Gesten. (2017). Report of the seventeenth conference of the Saudi Society for Educational and Psychological Sciences Gesten. $\quad$ Retrieved $18 \quad$ September, 2019 from http:/gesten.ksu.edu.sa/sites/gesten.ksu.edu.sa/files/imce_imimag/ktb_lmwtmr.compressed.pdf

Glennie, J., Harley, K., Butcher, N., \& Wyk, T. (2012). Open educational resources and change in higher education: Reflections from practice. Retrieved $24 \quad$ September, 2019 from http://oasis.col.org/bitstream/handle/11599/80/pub_PS_OER_web.pdf?sequence=1\&isAllowed=y

Hilton III, J., Larsen, R., Wiley, D., \& Fischer, L. (2019). Substituting open educational resources for commercial curriculum materials: Effects on student mathematics achievement in elementary schools. Research in Mathematics Education, 21(1), 60-76. https://doi.org/10.1080/14794802.2019.1573150

Hilton, J. (2016). Open educational resources and college textbook choices: a review of research on efficacy and perceptions. Educational Technology Research and Development, 64(4), 573-590. https://doi.org/10.1007/s11423-016-9434-9

Hilton, J. (2019). Open educational resources, student efficacy, and user perceptions: a synthesis of research published between 2015 and 2018. Educational Technology Research and Development, 1-24. https://doi.org/10.1007/s11423-019-09700-4

Kwak, S. (2017). How Korean Language Arts Teachers Adopt and Adapt Open Educational Resources: A Study of Teachers' and Students' Perspectives. The International Review of Research in Open and Distributed Learning, 18(4), 193-211. https://doi.org/10.19173/irrodl.v18i4.2977

Luo, T., Hostetler, K., Freeman, C., \& Stefaniak, J. (2019). The power of open: benefits, barriers, and strategies for integration of open educational resources. Open Learning: The Journal of Open, Distance and e-Learning, 1-19. https://doi.org/10.1080/02680513.2019.1677222 
Ministry of education. (2020). The establishment of the Ministry. Retrieved 7 September, 2019 from https://www.moe.gov.sa/ar/about/Pages/MinistryDevelopment.aspx

Mosharraf, M., \& Taghiyareh, F. (2016). The role of open educational resources in the eLearning movement. Knowledge Management \& E-Learning: An International Journal (KM\&EL), 8(1), 10-21. https://doi.org/10.34105/j.kmel.2016.08.002

National Center for E-Learning and Distance Learning (NCeDL). (2019). The OER program. Retrieved 19 March, 2019 from http://oer.elc.edu.sa/?q=en/programs

Roberts, V. (2019). Open Educational Practices (OEP): Design-based Research on Expanded High School learning Environments, Spaces, and Experiences. Doctoral Thesis. Faculty of Graduate Studies. University of Calgary. University of Calgary. Canada.

Sulisworo, D., Sulistyo, E. N., \& Akhsan, R. N. (2017). The Motivation Impact of Open Educational Resources Utilization on Physics Learning Using Quipper School App. Turkish Online Journal of Distance Education, 18(4), 120-128. https://doi.org/10.17718/tojde.340399

The official Saudi Press Agency. (2018). "Shams" wins the Excellence Award from the International Federation for Open Education. Retrieved 22 March, 2018 from https://www.spa.gov.sa/1743023?lang=ar\&newsid=1743023

Tosato, P., Arranz, B. C., \& Avi, B. R. (2014). Sharing Resources in Open Educational Communities. Qualitative Research in Education, 3(2), 206-231.

UNESCO. (2002). Forum on the impact of open courseware for higher education in developing countries. Final report. Retrieved 15 July, 2019 from www.unesco.org/iiep/eng/focus/opensrc/PDF/OERForumFinalReport.pdf

UNESCO. (2012). What is the Paris OER Declaration? Retrieved 27 May, 2019 from https://en.unesco.org/oer/paris-declaration

UNESCO. (2013). Why should I care about OERs? Retrieved 16 May, 2019 from https://en.unesco.org/oer/paris-declarationhttp://www.unesco.org/new/en/communication-andinformation/access -to-knowledge/open-educationalresources/why-should-i-care-about-oers/

UNESCO. (2017). International collaboration on Open Educational Resources (OER). Retrieved 18 April, 2019 from https://unesdoc.unesco.org/ark:/48223/pf0000247751_ara

Wong, T. L., Xie, H., Zou, D., Wang, F. L., Tang, J. K. T., Kong, A., \& Kwan, R. (2019). How to facilitate self-regulated learning? A case study on open educational resources. Journal of Computers in Education, First Online. Retrieved 12 April, 2019 from https://doi.org/10.1007/s40692-019-00138-4

Yuan, L., MacNeill, S., \& Kraan, W. G. (2008). Open Educational Resources-Opportunities and challenges for higher education. Retrieved 25 March, 2019 from http://ubir.bolton.ac.uk/290/1/iec_reports-1.pdf 